\title{
Strategic Communication: Outlining the Way Forward to Encourage Tax Compliance in Malaysia
}

Nor Suhaily Sufian Nory, Megat Al Imran Yasin, Syed Agil Shekh Alsagoff, Rosmiza Bidin

To Link this Article: http://dx.doi.org/10.6007/IJARBSS/v11-i7/10049 DOI:10.6007/IJARBSS/v11-i7/10049

Received: 24 May 2021, Revised: 29 June 2021, Accepted: 12 July 2021

Published Online: 25 July 2021

In-Text Citation: (Nory et al., 2021)

To Cite this Article: Nory, N. S. S., Yasin, M. A. I., Alsagoff, S. A. S., \& Bidin, R. (2021). Strategic Communication: Outlining the Way Forward to Encourage Tax Compliance in Malaysia. International Journal of Academic Research in Business and Social Sciences, 11(7), 1549-1570.

Copyright: (c) 2021 The Author(s)

Published by Human Resource Management Academic Research Society (www.hrmars.com)

This article is published under the Creative Commons Attribution (CC BY 4.0) license. Anyone may reproduce, distribute, translate and create derivative works of this article (for both commercial and non-commercial purposes), subject to full attribution to the original publication and authors. The full terms of this license may be seen at: http://creativecommons.org/licences/by/4.0/legalcode

Vol. 11, No. 7, 2021, Pg. 1549 - 1570

Full Terms \& Conditions of access and use can be found at http://hrmars.com/index.php/pages/detail/publication-ethics 


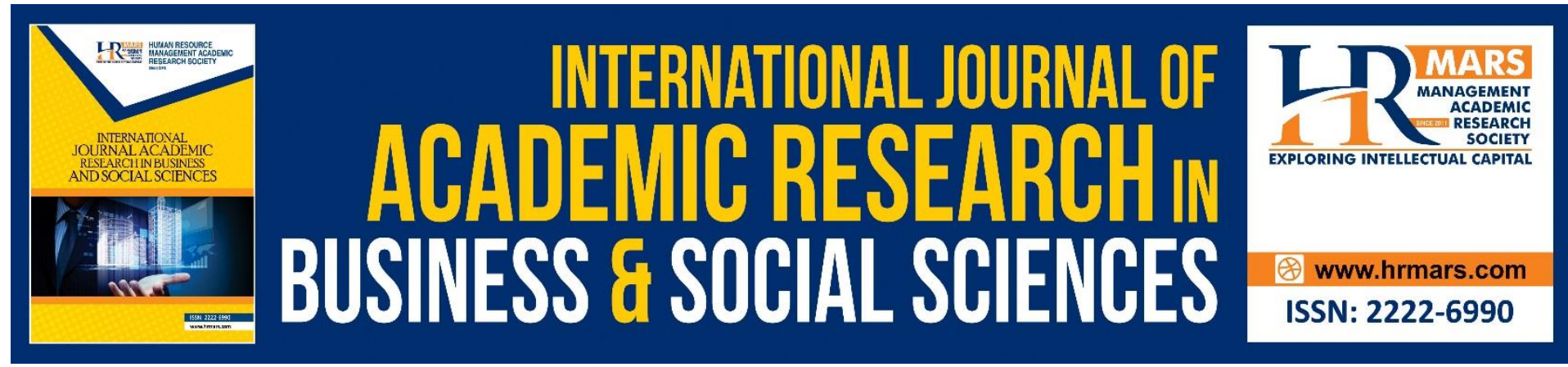

\title{
Strategic Communication: Outlining the Way Forward to Encourage Tax Compliance in Malaysia
}

\section{Nor Suhaily Sufian Nory, Megat Al Imran Yasin, Syed Agil Shekh Alsagoff, Rosmiza Bidin}

Department of Communication Faculty of Modern Languages and Communication

University Putra Malaysia

Email: norsuhaily.sufiannory@gmail.com

\begin{abstract}
Communication should be regarded as constitutive on the basis of proper preparation, proper execution and ongoing assessment. In this study, the scope of the strategic communication can be viewed in the context of approaches, models and concepts. This research will perform the data analysis in a qualitative manner. In this regard, Barret's strategic employee communication model was found to be relevant to the context, in which this study will be conducted. This research is intended to discover the way out for contact issues between top management and subordinate workers, followed by targeting clear communications, disseminating the efficacy of media and platforms to taxpayers in Malaysia. Strategic communication is often approached from the viewpoint of efficiency of communication and its effects on the organization. Hence, the purpose of this review is to identify the strategic communication practice by Inland Revenue Board of Malaysia (IRBM) in order to strengthen tax compliance in Malaysia. This review has suggested that strategic supportive management, targeted message and media/ forum platform are capable of strengthening tax compliance in Malaysia.
\end{abstract}

Keywords: Strategic Communication, Management, Taxpayers, Tax Compliance, Inland Revenue Board of Malaysia

\section{Introduction}

Communication plays a vital role in the life of leaders or managers of any organizations who are working at the top-level. In order to reach the goals of the companies effectively, the communication skills of CEOs and senior executives of an organization need to be strong and powerful. This is mainly because managers are the ones who would spend most of their days for building up skills, promoting awareness, managing activities, and many others. Thus, possessing good communication skills plays a vital role in the life of the managers, owing to the fact that they are, 70 to 90 percent, engaged in communication with the employees (Mintzberg, 1973; Eccles \& Nohria, 1991). Therefore, organizations need to organize communication strategically to avoid any shortcomings that could result in the inability for 
the message to be conveyed and transmitted properly (Mahbob et al., 2019). This shows that employee-focused communications need to be incorporated in ways that would ease the workers to absorb and recognise the rules, while at the same time encouraging the workers to follow management orders; in which successful and effective media/ forum can also be considered as the strategic employee communication.

The Strategic Employee Communication Model is capable of assessing and improving the communications among the employees and thus, forming the foundation for the strategic employment to facilitate change (Mahbob et al., 2019). Therefore, in order to avoid misunderstanding among the organizations, effective management of strategic communication is necessary. Besides, in Inland Revenue Board of Malaysia (IRBM), it is investigated that strategic implementation of communication has even begun for tax compliance measures. This is found to be in compliance with the status of IRBM as one of the main recognised agencies under the Ministry of Finance Malaysia, which is responsible for raising and managing all of the country's direct taxes. In simpler terms, tax compliance means compliance with tax reporting requirements, by which the taxpayer would file all of the required tax returns at proper time and that the returns would accurately report tax liability in accordance with the tax laws, regulations, and court decisions applicable at the time the return is filed (Roth et al., 1989).

Based on the value of driving tax compliance in Malaysia, the IRBM aims to introduce successful strategic coordination within the organisation to ensure that the IRBM remains consistent and dedicated in attracting taxpayers, as well as fostering tax compliance in Malaysia; being regarded as a central agent of the Malaysian Government. In this context, the purpose of this paper is to acknowledge the supportive management of strategic communication as a key pillar in achieving the organization's objective of identifying strategic communication methods used to encourage tax compliance in Malaysia. In addition, recent research has also reflected on the value of providing employee-specific correspondence in a more accurate and productive way. Constructive communication could act as a paradigm change and encouragement in motivating workers to execute assignments properly. Not even that, this study has also revealed the power of the media/forum that has been used as a core management mechanism in the IRBM for relaying all knowledges to their workers, which has further demonstrated that the problem of distance has no longer existed nowadays, as leaders could interact or communicate with any levels of staff, no matter where they are.

This study has employed Barret's Strategic Employee Communication Model (2002) as its main structure and forum. In this regard, Barret has highlighted the facets of supportive management, targeted message, effective media/forum, well-positioned staff and ongoing assessment. To explain, the position of leaders and coordination is complemented by the responsibility of leading the organisation to the desired direction. In this sense, members or administrators are required to assist all corporate tasks. This is due to the fact that operation would only be able to run smoothly if public communication is properly executed by the chief or the upper management. Communication that includes careful preparation, proper execution of plans and continuous assessment of messaging could ease organisations to recognise issues and take decisive steps, hence fixing them before they become cancerous (Mahbob et al., 2019)

\section{Strategic Supportive Management}

The first highlight of the paradigm, which is the impetus for upper management, is the act of inspiring managers who are at the top of the organisational hierarchy and responsible for the 
organisation as a whole (Nasurdin, 2006). The assistance given is not only in the form of plans, but also in the form of involvement (Makhbul \& Hasun, 2003). In addition to motivating workers, managers are also expected to play a charitable role in directing personnel, convincing their subordinates to comply with and follow all directives relevant to their task, being compliance with organisational expectations and emphasising the value of working together; which would encourage managers and employees to be in good relationships, set high levels and be able to inspire employees. This charitable role is believed to be directly related to the personal trait that should be possessed by a quality leader, which is the trait of empathy (Mansor \& Hamzah, 2015). An empathetic leader is a leader who understands the feelings and abilities of others, as stated by one of study participants, "(Empathy) should be present because when we put ourselves in other people's situations, I think he or she will have more "insight" over what we feel and what we propose". This explains that empathy is an interpersonal development that needs to be taken into account in stimulating leaders' development (Drew \& Ehrich, 2010). In this matter, leaders should possess interpersonal communication skills in order to establish relationships with all levels of staff easily. Similarly, as stated in the Management Competency Model introduced by Hogan \& Warrenfeltz (2003), interpersonal skills are among the competencies that have been identified as necessary in a leader. Interpersonal competence is the ability to build and maintain relationships between leaders and staff (Hogan \& Warrenfeltz, 2003). Thus, communication skills are important for building good relationships with staff (Mansor \& Hamzah, 2015) as emphasized by the previous researchers, namely Spendlove (2007) and Bush (2008); who have emphasized on the importance of staff management skills among leaders.

Research conducted by Mansor \& Hamzah (2015) has also found that leaders must possess three types of competencies while dealing with employees, which include giving encouragement, developing strong connections, and caring after the well-being of employees. In this context, leaders must always encourage their employees and the act of giving encouragement to these employees is also underlined as a quality that a leader must have, as stated by Spendlove (2007); Boyatzis (2011). This encouragement could happen in a variety of forms, such as addressing the physiological and psychological requirements of the employees, awarding prizes, or even 'touching' the staff's hearts by being understanding. According to Kouzes and Posner's (2002) Leadership Practices Inventory (LPI), leaders should motivate employees by acknowledging their efforts and applauding their accomplishments and staff should be encouraged, regardless of the type of award offered. The institution's aims would be more efficiently realized if its employees are motivated (Mansor \& Hamzah, 2015). Moreover, building good relationships with staff is important for the leaders to know the staff better and easily get cooperation from the staff. Also, leaders need to be fair to all staff for building good relationships. Leaders can build good relationships in a variety of ways such as celebrating staff, spending time relaxing and playing sports or having meetings with them. Boyatzis (2011) has also suggested that leaders need to build a close relationship with their staff by establishing a trust -based relationship with their subordinates. In handling staff, leaders are expected to take care of the welfare of staff, which include their general personal affairs. The welfare of the staff must be taken into consideration, so that leaders can provide appropriate assistance whenever necessary. Oftentimes, leaders who look after the welfare of staff would encourage their staff to work even better (Mansor \& Hamzah, 2015).

In addition, managers need to empower employees' intellectuals by encouraging them to constantly increase consciousness, take various paths and have creative, innovative and revolutionary thought together with challenges and the passing of time; to consider 
stressing on the needs of employees and understanding the potential of their employees to thrive better; (Bass, 2008; Rasid, 2007). Organizations that implement better communication strategies are believed to be able to solve challenges, particularly during the transformation phase, at each stage, along with suitable methods (Klein, 1996). Since the contact strategy is a holistic plan, Murphy's (2008) analysis seeks to control the general public in order to ensure an improved efficiency. The elements of the partnership method include goals, forecasts, strategies, core concepts, platform selection, consolidation and evaluation.

According to King's (2009) analysis, the strategy should be something that is finished and would take effect. For instance, the top management of the IRBM has ordered their Department of Ethics and Risk Management (JIPR) to send a strict warning email to all personnel ranks that disciplinary action will be taken promptly if there is any indication that any staff have verbally or written or leaked any sensitive information to the press. The intended contact strategy is to publicly represent the company and win employees' respect by sending them an alert before obtaining data from other sources. This is because methods of engagement are part of good approaches for management. In recent years, contact management strategies have become important due to workplace changes, the evolution of expectations of the communication system and communication knowledge, as well as the actual realities of the business (Walker, 2011). Hassan et al (2015) have concluded that the assistance from management plays an important role in strengthening the relationship between the efficiency of internal audit, which is directly connected to the execution of contact activities. As such, it does not only offer employees the ability to display their current abilities but also increases the confidence among staff to attempt new tasks. In this regard, support from management can be found in terms of recruitment and training for workers to improve their skills. It is expected that the skills, typically acquired from continuous understanding, experience and preparation; will enhance the capacity of workers to perform activities and further improve the quality of work (Zakaria, 2012). A crucial success driver for the task group is the encouragement of upper management. This is how they would be able to reduce mistakes and prevent delays in running and handling a project with the help of management (Young \& Poon, 2013). Top management support is recognised as an important element in the performance of the corporate structure of a company (Shao et al., 2016). In terms of work satisfaction and organisational engagement, from the perspective of the Korean countries; the relationship between human resource growths, top management support and staff actions is found to be vital. The production of human resources possesses a beneficial relationship between encouragement from upper management, employee satisfaction and organisational engagement. The findings of the study have showed that when top management has specific priorities and is supported in its execution by the creation of good human resources, the workers will definitely provide full commitment to their duties (Lee et al., 2017)

\section{Strategic Targeted Message}

To meet the goal, obtained and sustained by the target, a message must be assured (Abdullah, 2002). The feasibility of channelling messages to the general audience is doubted by most administrators. The issue that is always asked is why the public has not changed its mentality, even after a lot has been done to disseminate information (Rosli, 2016). Therefore, to ensure that the message meets the desired target, constant exposure of the message should be performed for a suitable amount of time. Therefore, the content of the message and its usefulness must be conceived and checked for the intent of each message to be transmitted. 
By stressing the use of digital media to support the transmission and distribution of messages efficiently and rapidly (Omar et al., 2015). When digital technology evolves and is used by the public regardless of age, good use of new media will have a significant effect on the organisation. Organizations also need to take necessary action such that targeted communications can be successfully delivered. Barrett stresses the value of targeting communications along with audience-tailored knowledge by proposing organised communication to provide proactive and targeted key objectives to ensure strategic communication. Therefore, for effective communication, Barrett proposes two detailed factors, namely the relationship between corporate priorities and personnel communication, which must be one in which such aspects entail the value of directly engaged top and secondary management and responsible for up, down and around the company communication. In fact, for different markets, Barret supports different communicative methods and knowledge should be adapted to the audience and terms should be selected differently. For starters, it can be expected that the phrases should be different for manufacturing workers and headquarters as well as for employees in other departments (Mahbob et al., 2019). For various categories, Barret often encourages various contact strategies and information should be adapted to the audience and words should be used differently. For starters, it can be inferred that the requirements should be different for manufacturing workers and headquarters, as well as for employees in other departments (Mahbob et al., 2019).

\section{Strategic Effective Media/ Forum}

Employees should be exposed with the use of email, community discussions and internet facilities to enhance connectivity while indirectly increasing the exchange of knowledge and the speed of distribution of messages and documents (Zookefli \& Nor, 2008). In line with this, Abdullah \& Tahir (2014) have suggested that recent technical advances should be employed by management. This is due to the fact that communication technologies are part of media and communication systems. There are numerous apps such as WhatsApp, Telegram, WeChat, Facebook and so on in the media and contemporary networking technologies that would make communication possible without hindrance. While a message is publicly embraced, it varies according to its motivation, experience and understanding. These variations impact how the message is delivered and which platforms are used, as most audiences do not have the same preferences and needs, coupled with diverse views that are shaped by familiarity and information level (Rosli, 2015). It is also observed that the value of information technologies as a medium for communicating the message has a positive effect on the company and top management (Abdul Aziz, 2016). Through leveraging diverse tools in accordance with new trends and technologies, IRBM aims to provide the latest data to all layers of workers. The use of WhatsApp communities, emails, short videos, memos, official support desks and other contact resources is generated so that communications could be transmitted easily, reliably and properly, while at the same time be obtained by all levels of workers. Not all audiences have the same preferences and expectations, along with different attitudes shaped by experience and knowledge levels (Rosli, 2015). Thus, due to desire, practise and awareness, public reception of a message varies. For example, when the Movement Control Order (MCO) was implemented by the Government starting March 18, 2020 nationwide due to the spread of the Covid-19 pandemic, IRBM had used all of the available communication channels to disseminate information to all levels of workers without hesitation. This includes a stern warning message pertaining any form of Caring Assistance 
(BPN) information announced by the Government at that time, which will not be shared arbitrarily to the public if there is no authentic and accurate source of reference. This means that activities within the organization can be improved with the help of communication technology and they require comprehensive cooperation and commitment from all parties to ensure the selected technology has a positive impact, even if one of the employees in the organization has to deal with public inquiries. Therefore, the selection of the right communication channel is important in disseminating information accurately and increasing the effectiveness of communication. (Mahbob et al., 2019)

Management that regulates and encourages engagement within the organization while creating healthy working relationships will also be discussed in this research. This will be followed by a tale by each Department/ State / Branch on the appropriate, substantive and coherent message objective by adapting essential messaging to workers and, if possible, ensuring the message to be distributed remain organized with elements that could be quickly digested and grasped by all employees at different levels. Finally, the analysis will be further examined by describing the efficacy of the media/forum used by the IRBM to facilitate tax enforcement in Malaysia.

\section{Strategic Communication Literatur Review Strategic Supportive Management}

Strategic communication has been characterized as a paradigm for analyzing communication as a set of goal-oriented actions carried out by companies with a mission and objectives (Hallahan et al., 2007). The overarching goal is to maintain positive relationships with all stakeholders, so that the organization's strategic goals may be realized (Steyn, 2004; Zerfass, 2007; Cornelissen, 2008). In this sense, Day et al. (2017) have found that when there is less strategic communication connected to long-term objectives and planning, trust decreases and emotional conflict arises among members of the company. Therefore, management and workers are less enthusiastic without efficient strategic communication, which has an impact on the quality of day-to-day work. In order to guarantee organizational stability, the selection of an appropriate communication strategy is necessary. However, (Juholin et al., 2015) have concluded that strategic communication will never be "effective" if it is primarily dependent on top management's joint logic and personnel persuasion. Throughout history, CEOs have been disappointed with personnel's lack of comprehension of the strategy (e.g. Kaplan \& Norton, 1992; Aaltonen et al., 2001; Doz \& Kosonen, 2008).

As mentioned explicitly in their study model, strategic communication may be one-way and two-way, controlled and dialogical, planned and spontaneous, with the possibility of perfect control being lost. When addressing strategic communication, Juholin's strategic employee model theoretically has mirrored the former with top managers' communication perspectives in order to highlight the model's shortcomings or practical limitations, as well as the possibilities with strategic management perspectives (Juholin et al., 2015). 
Figure 1: Qualities of Responsible Dialogue (Juholin et al, 2015)

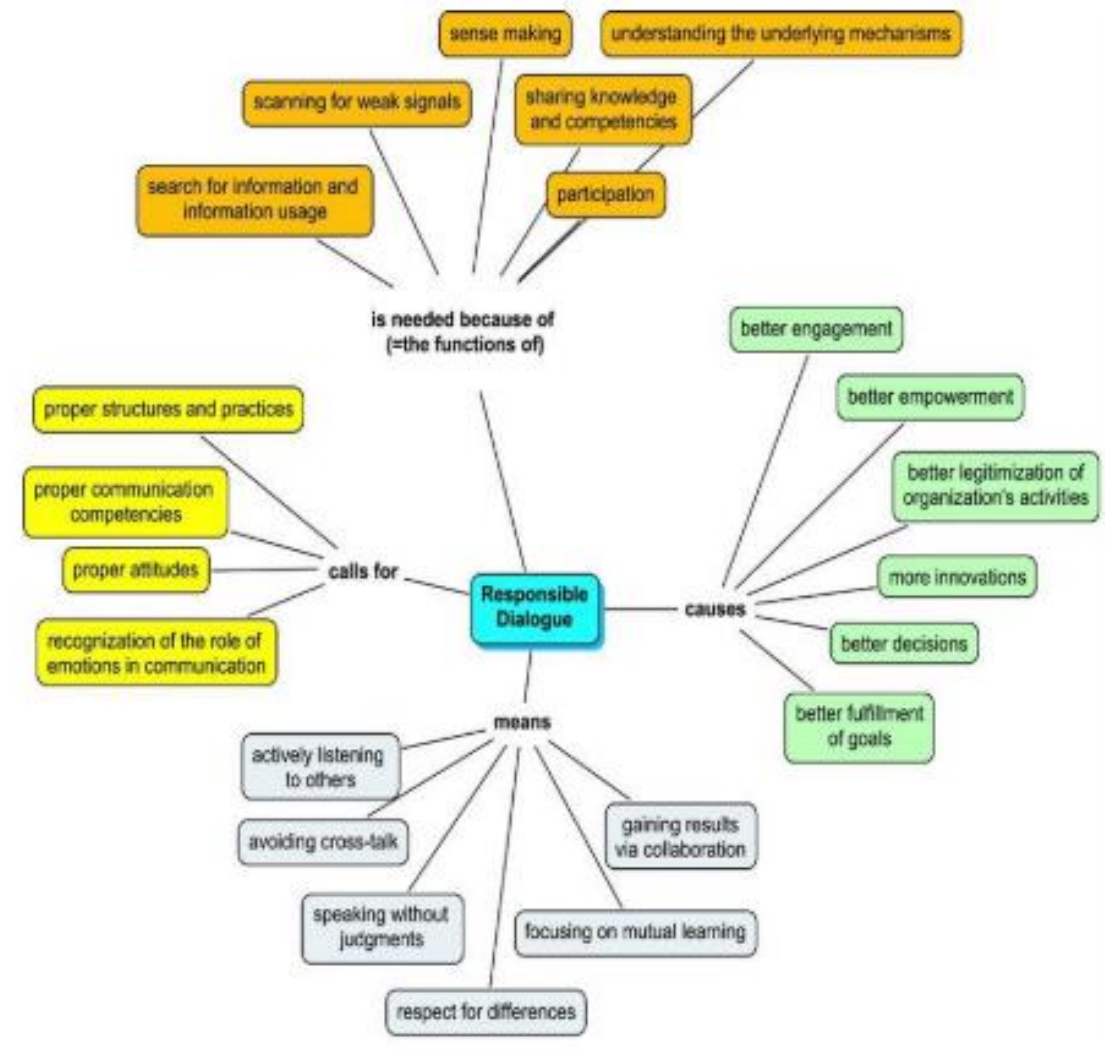

Juholin's model has proposed the following dimensions for strategic employee communication: this is about knowing and sharing things, conducting discussion and interaction on meaningful and complicated issues; this is about making sense of things, building a sense of community; and this is about belonging to the organization and creating a sense of togetherness (Juholin et al., 2015). According to Juholin's model, the fourdimensional structure of their study includes older communication models but also complements them with "newcomers," responsible dialogue. Responsible dialogue may appear idealistic, but it contains elements that may be unacceptable to the organization. As a result, the following threats can be identified; in order to be realistic, every organization has confidential issues such as interpersonal rivalry, trade secrets, and sensitive information that should not be discussed openly for a variety of reasons. Large differences in opinion and principles between individuals and groups of personnel may pose an implicit problem for dialogue. Long-term communication can also stymie processes and jeopardize other businesses or operations. In this sense, all communication models have a place, and none are obsolete in strategic employee communication. At the same time, this model believes that strategic communication goes beyond the dissemination of facts; we believe that every organizational work possesses feelings and emotions, and denying their existence is tantamount to denying humanity (Juholin et al., 2015). In the workplace, dialogue must be handled just like any other operations or processes. It necessitates debate, reaction, and reflection, as well as working under time and cost constraints. Furthermore, individuals' readiness and willingness to change their communication depend on the circumstances, in which dialogue has varying opportunities to be fulfilled. Organizational culture, which is based on communication, has a strong influence on dialogue. As a result, change necessitates time, personal involvement on the part of superiors, and visible action. Dialogue is reduced to mere 
"theatre" or a superficial process of engaging people in its hypocritical form, which immediately results in loss of credibility. Simultaneously, Juholin's model has also suggested a more comprehensive approach to strategic employee communication. The journey begins with a map of strategic thinking and current strategic communication. White areas, like actual chart making, remain unmapped. In this matter, Juholin et al. (2015) have recommended mapping, which at least the following areas should be charted; the fundamental characteristics of responsible discourse, as well as their relationship to previous communication models, should be extensively investigated. It is necessary to expound on the benefits, possibilities, and pitfalls of responsible discussion within the corporate contexts. It is necessary to assess the communication skills of responsible discussion participants. Finally, the function of communications management and human resource development should be highlighted (Juholin et al., 2015).

While Mazzei (2010) based model (Figure 2) has promoted the link between external and internal organizational communication practices on an external communicational level, Ahmad (2016) has emphasized on the importance of sharing knowledge, collaborating on ideas through various channels using various communication tools, and crossing organizational boundaries by implementing new strategies for communicating with people. The total pattern of external communication can be seen from the results of external communication: the creation of external business knowledge, participation of external knowledge to aid in the expansion of state government business vision, and state government branding on a regional and global scale (Ahmad, 2016).

Figure 2: The Model of Strategic Communication (Mazzei, 2010)

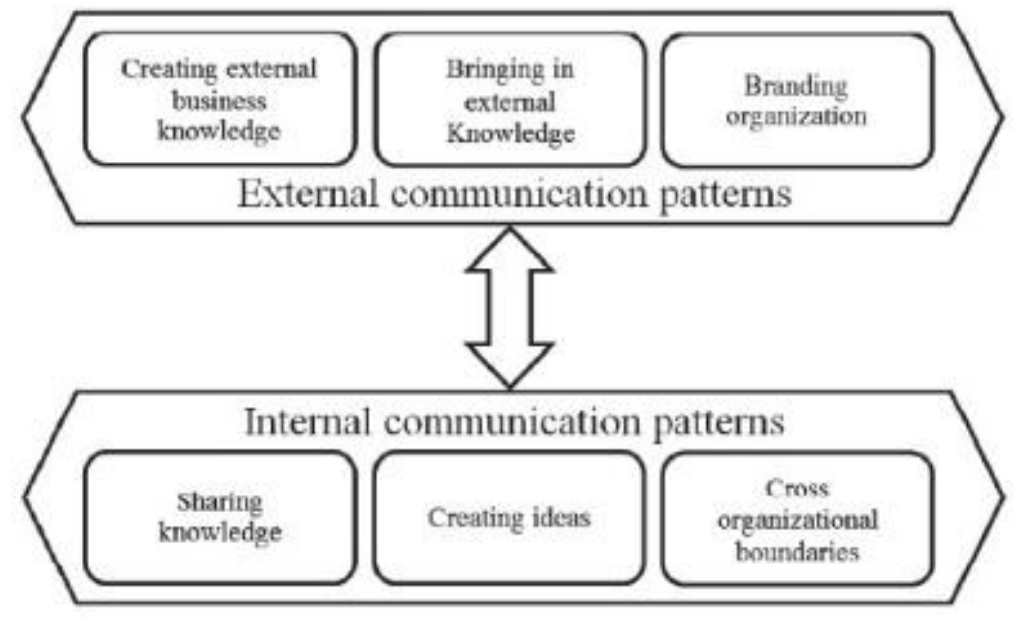

Based on these two models, there is one item that is not emphasized, namely strategic supportive management. To elucidate, these two models solely focus on their own parts and do not emphasize the relevance of strategic supportive management, as stressed in Barret (2002) study model. According to Barret (2002), Barret's strategic employee model is designed to assist management in comprehending the strategic role that is carried out by communication in the day-to-day performance of any firm and may aid "everything" and "publishing" - limited perspectives of communication. Simultaneously, Barret study model also has provided analytical tools for diagnosing company communications strengths and weaknesses and designing changes for realizing communications plans and programs by capturing all key components of employee communications while linking them to one another as well as company strategies and operations. 
Figure 3: Strategic Employee Communication Model (Barret, 2002)

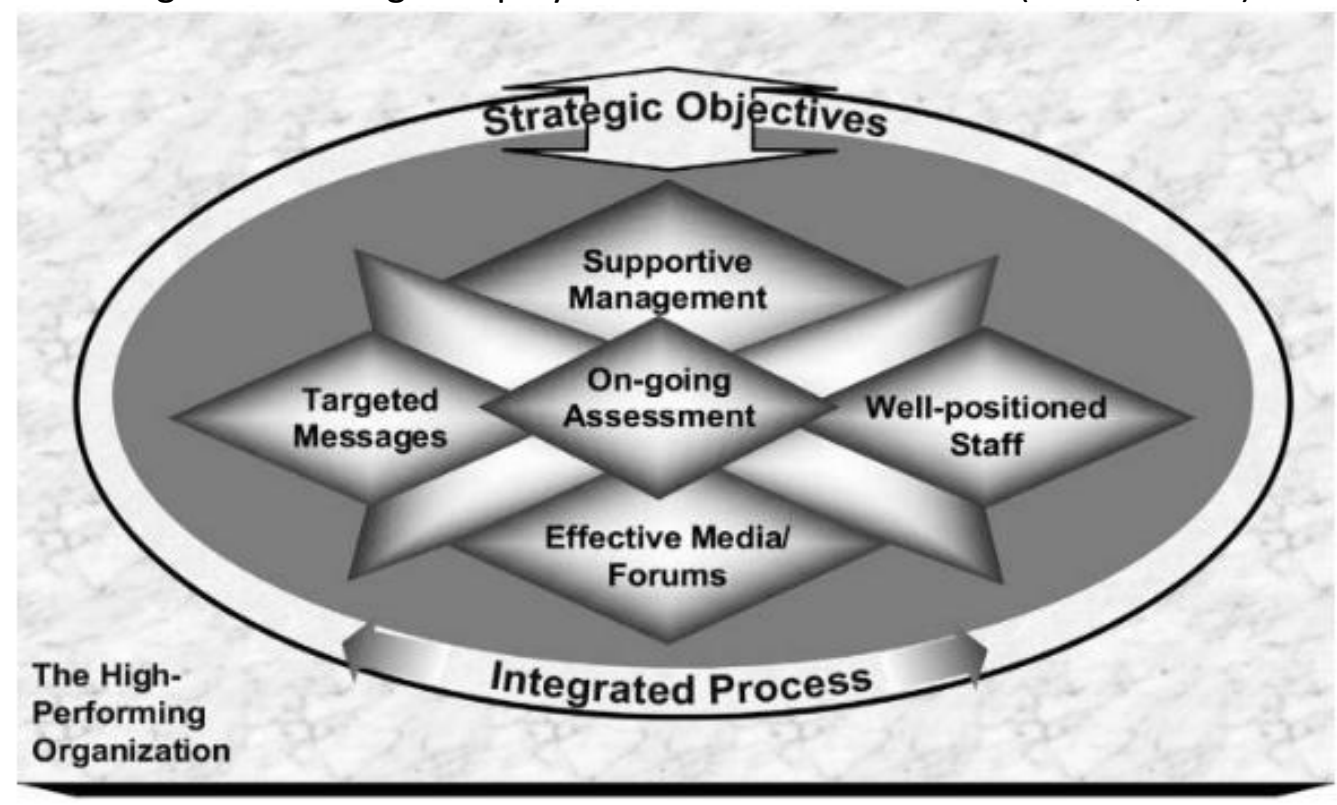

The finest definition of supportive management has arisen as a consequence of research on examples of good employee communication. According to Barret's (2002) definition on this matter, top-level and mid-level management must be personally involved in and responsible for communications up, down, and across the business. Communication is not merely what the communication team performs in a significant transition circumstance or in day-to-day operations. Instead, managers must demonstrate the conduct that they demand from their people, as the old cliché goes, "walking the talk", in which they should set the tone for an open or closed information flow. Without them, communication lines would not be able flow freely. Barret (2002) has developed his study model with the hope that the change in its method would assist in elevating employee's communication to a more strategic level of recognition and operation, hence facilitating large change projects. As a result, it may be regarded as the ticket that propels a firm to be on the top of the list of successful transformation initiatives (Barret, 2002). Furthermore, Barret's idea of emphasizing the importance of strategic supportive management is also in line with Andersson's (2019) study, in which Andersson (2019) has tested four hypotheses (Figure 4) that suggest that; an open internal communication climate, immediate supervisor communication, top management employee communication, and perceived importance of communication, are all capable of influencing employees' predisposition to take communication responsibility 
Figure 4: Strategic Employee Framework - Hypothesized Model (Anderson, 2019)

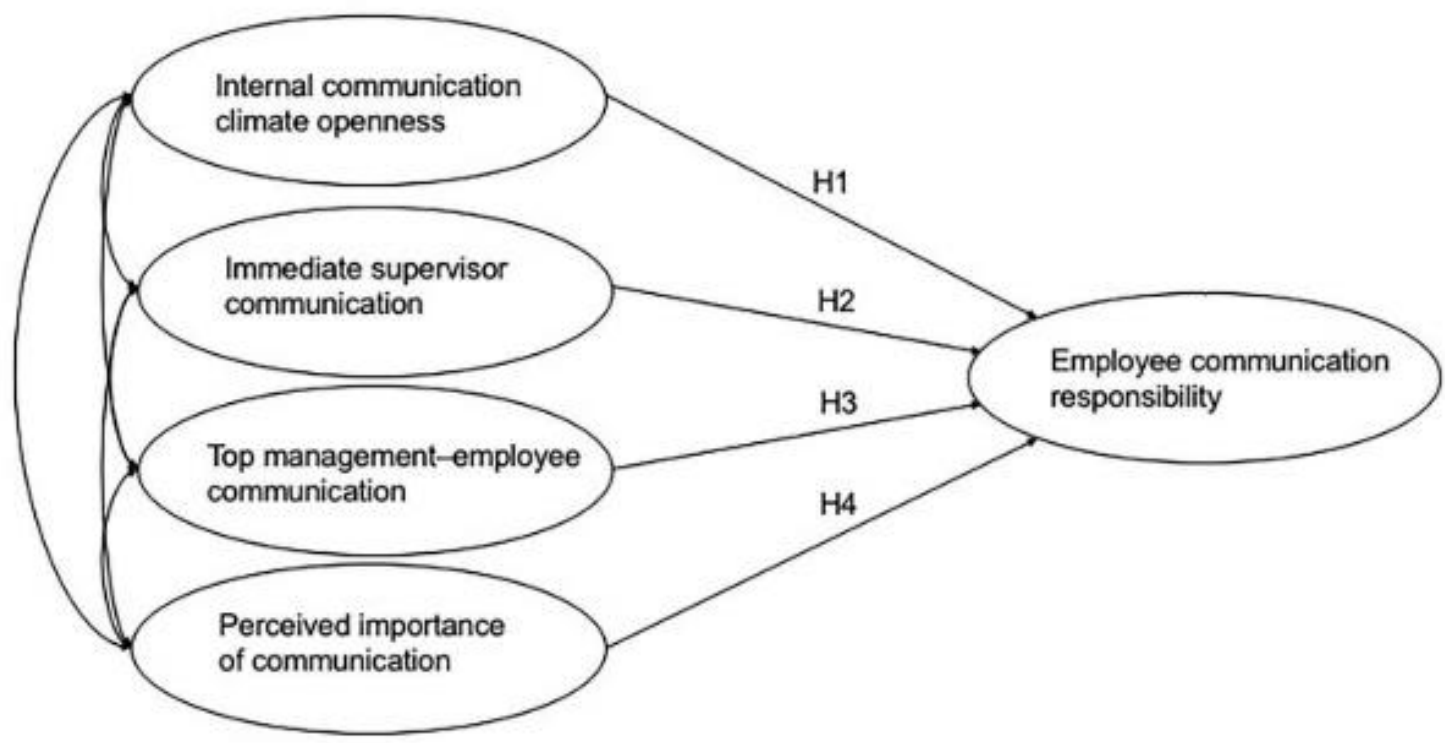

The findings of Anderson (2019) have indicated that all the four criteria have a considerable impact on co-worker's communication responsibilities. The biggest benefit is obtained from an open internal communication atmosphere, followed by direct supervisor communication, perceived significance of communication, and top management-employee communication. The findings of this study have supported this suggestion and idea further, as far as the hypothesis that top management-employee communication contributes to employees' proclivity to take communication responsibility is concerned, and it thus strengthens the findings of previous research that have emphasized on the importance of well-functioning communication between top management and employees. The findings show that communication practitioners should study and develop tactics to improve the top management communication in order to increase visibility and transparency, while boosting the workers' proclivity to uphold communication responsibilities. To relate, Anderson (2019) has contributed to employees' communication research by establishing the notion of employee communication responsibility and finding four characteristics that would influence workers' proclivity to uphold communication responsibility. This study has demonstrated that employee communication is a complicated topic, and communication practitioners must consider a variety of organizational aspects in the strategic management of organizational communication in order to increase employees' feeling of responsibility (Anderson, 2019). Meanwhile, Luthra (2015) has also stated in his model (Figure 5) about how changes in communication style would affect the impacts of change. In some styles, such as when dealing with difficult or vital issues; the leader must be forceful and the leadership style will be authoritative, but he must maintain control over his communication, or else, miscommunication or ineffective communication would happen. In another example, if one has to deal with a group of individuals who have diverse attitudes and working styles, he should be more focused on people and communicate in such a manner that he could speak on an individual level while dealing with the group. Finally, Luthra (2015) has also asserted that communication and leadership are inextricably linked and cannot be accomplished separately. 
Figure 5: A Conceptual Model for Effective Leadership Communication (Luthra, 2015)

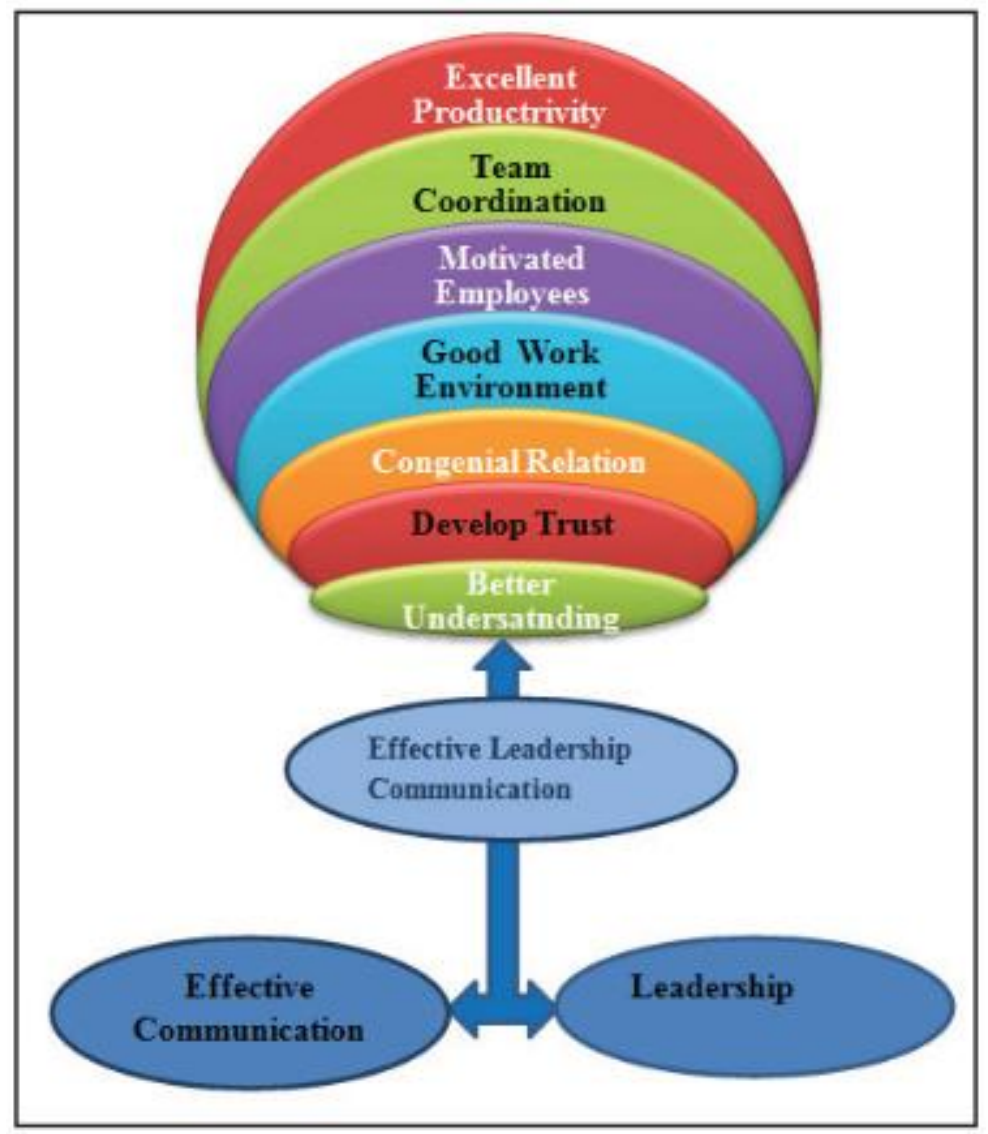

However, these questions are unexplainable since the notions differ from person to person and each individual has his or her own views on what is going on around them. In relation to this, Luthra (2015) has developed a Conceptual Model for effective leadership communication based on the aforementioned discussion and knowledge of the principles. Effective communication and leadership, according to this paradigm, go hand in hand to improve the understanding between team members and leaders or managers. This is due to the fact that more knowledge would develop trust elements, which are critical for collaborative work. Trust would then foster strong connections, which in turn promotes a positive working environment, in which people are driven and enriched with self-confidence and work in coordination; by which this coordination allows them to achieve their optimum performance by meeting individual and team goals (Luthra, 2015).

However, it could be observed that these five models do not focus and address the supportive management. This explains the reason as to why this study has employed the strategic model of employee communication by Barret (2002) as a guide and the main compass that is of interest in this study. This is because Barret's (2002) model is capable to serve as an analytical tool to diagnose company strengths and weaknesses in employee communication by explaining the Strategic Employee Communication Model and defining best practices, demonstrating change communication approaches to improve employee communication using the Strategic Employee Communication Model, and providing case studies on the effectiveness of the use of models and approaches during program change (Barret, 2002). 


\section{Strategic Targeted Message}

Targeted messaging is also connected with communication efficacy. Message targeting entails identifying a specified audience in order to ensure that the message is delivered to the intended recipient (Pate \& Buchner, 2013). According to (Figure 3), Barret (2002) has defined the best practice for targeted message as information tailored to the audience (ie messages in various language for various persons when necessary), in a way that such information is relevant and meaningful while, at the same time, being consistent. As a result, each business unit or division must customize critical communications to its workers, and if required, turn the corporate centre's overall message into digestible and actionable communications that workers could comprehend and act on (Barret, 2002). In line with this, Barret (2002) has also mentioned that the survey has revealed serious communication issues, particularly in these aspects: messages are inconsistent and not targeted to reach all employees at all levels; employees across the board are unsure of the company's direction; many are afraid to express their ideas or concerns; management appears to be isolated and does not accept field operations; and overall, the company focus too much on external communications, too many publications, and direct internal communications that aren't meaningful enough (Barret, 2002). A critical issue worth to be pondered is the lack of top-level management commitment and follow-through on communication, as well as lack of management communication training on interpersonal skills. In this sense, we have discovered in the employee survey that the major themes or key messages inside business units and across the firm have changed frequently, resulting in confusion and doubt among employees pertaining the organization's vision and direction, while at the same time; the interactive, two-way communication is also found to be absent. Finally, though communication efficacy was monitored on a regular basis inside the business, it was not linked to individual job performance at any level; consequently, communication was not considered as a crucial obligation for all employees, from managers to front-line workers (Barret, 2002).

Meanwhile, Blazenaite (2012) has noted in his research model that the study on communication systems is extensive in scope and has left some parts that have not been fully addressed conceptually. This could be supplemented by investigating additional communication issues central to effective organizational functions and communication systems, such as the relationship between knowledge management and communication, intelligent emotional management, and communicating about organizational uncertainty. Nonetheless, despite the fact that some of the topics discussed in the article are still being explained, the applicability and practical relevance of the presented research methodology may be recognized. In other words, by utilizing the created structural model and the provided criteria, corporate communication systems may be practically constructed and audited, while their communication characteristics would be assessed, and the potential improvements are recognized. 
Figure 6: Theoretical Structural Model of a Communication System at an Organization (Blazenaite, 2012)

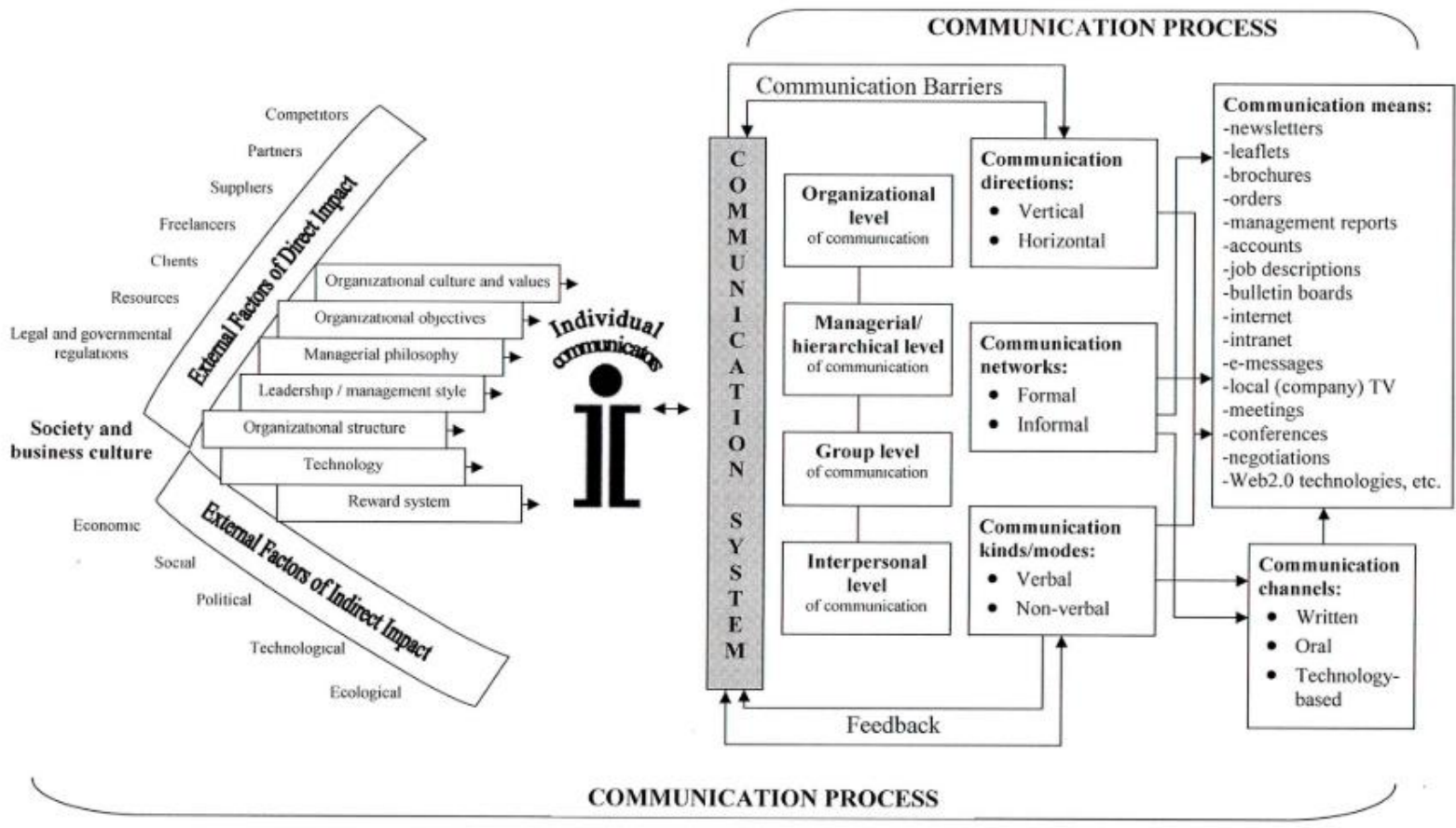

Leadership is an art that unites individuals from various groups to develop connections amongst humans in order to achieve certain goals. In order to attain the required level of leadership, communication skills are deemed important, especially in expounding the needs of the vision and purpose so that the path to be undertaken and followed becomes apparent. Communication is essential in developing a communicative connection as leadership entails the process of leading, guiding, influencing, or regulating thought. In this matter, organizations might fail to achieve their vision and goal if the top management group fails to communicate the vision and mission's needs and aspirations to the implementing group. The capacity of the highest group to communicate with the implementing group will be used to measure the organization's success (Akhtar \& Azmi, 2017). This is backed by Abd. Ghoni et al. (2017), who have contended that efficient information transmission is linked to communication, which determines organizational management practices. This is due to the fact that precise information distribution is critical in order for the recipient of the information to complete the prescribed task flawlessly and within the time frame specified. According to Abd. Ghoni et al. (2017), WhatsApp is the greatest and most successful medium of information transmission since it is one of the fastest platforms used and reached by the employees. Poor communication, according to Akilandeswari et al. (2015), is the root cause of organizational collapse. This is due to the fact that poor communication is the root of all difficulties, whether social or professional. Therefore, the clarity of idea and expression, correctness and appropriateness of the message, short and succinct message, favourable atmosphere, feedback, and completeness of the message by addressing all areas of message delivery, according to him; are among the factors of communication efficacy (Mahbob et al., 2019). 


\section{Strategic Effective Media/ Forum}

Omar et al. (2015) have emphasized on the use of new media to facilitate the transmission and distribution of messages in an efficient and timely manner. As new media evolves and is utilized by audiences of all ages, appropriate use of new media may have a significant influence on the organization. As a result, companies must take proper steps to ensure that the targeted messages are properly implemented. This assertion is supported by Mahbob et al. (2019), who have noted that the message should be continuously disclosed for a fair amount of time to guarantee that it reaches the desired target. As a result, each message to be transmitted must be produced and examined for substance, as well as efficacy, to the target. Barret (2002) has stated that the traditional communication components, such as messages and media, are at the centre of the model. However, the direct link between strategic goals and the company's plan, and the overlapping of supporting management with the ongoing evaluation of communication between individuals and companies; have shifted the model from a tactical level to a strategic one. Hence, the finest definitions of successful media/forum has stemmed from Barret's (2002) research into firm examples of good employee communication (Figure 3). Effective employee communication employs a variety of mediums to reach its consumers, but it prioritizes direct, face-to-face contact above indirect, printed, or electronic media. As a result, all managers must get proper training for enhancing their interpersonal communication, meeting management, and facilitation (Barret, 2002).

Figure 7: Accompaniment Difficulties (de Lima et al, 2019)

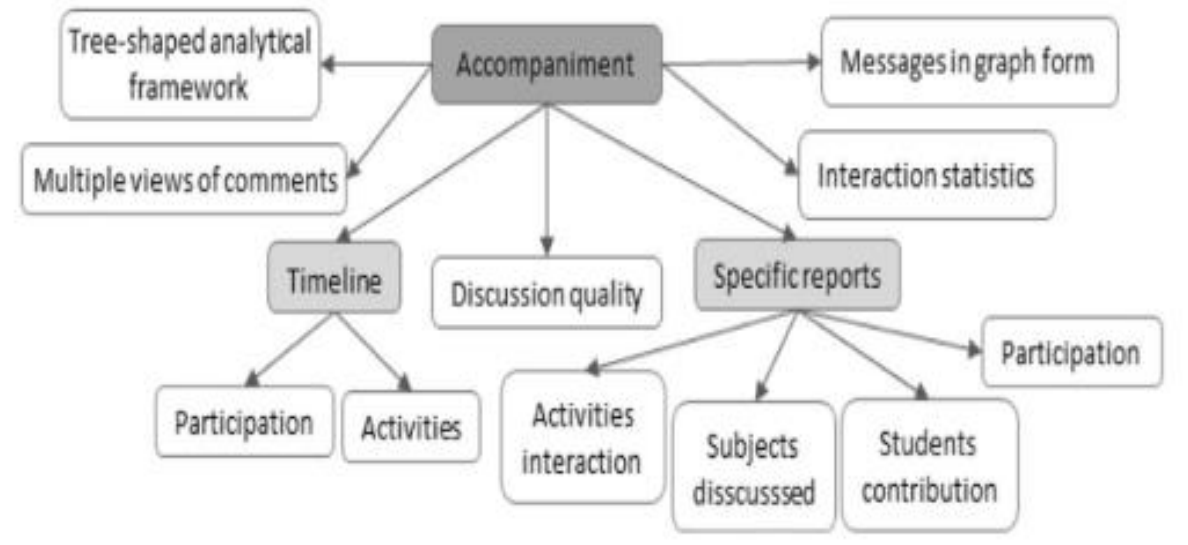

Meanwhile, de Lima et al (2019) have addressed the efficiency of forum in their research, in which they have found that less experienced instructors have reported difficulties due to the lack of tools for monitoring forums: "As a lot of people write a lot, I can't keep up ; I just monitor forums because a lot of people make posts." Therefore, depending on the purpose, many people write, but sometimes - they are not as objective as they should be. To relate, Figure 7 has depicted the structure of accompaniment difficulties. It has outlined the difficulties and needs that are identified within the instructors' reports, emphasizing on the lack of resources among instructors to assist them in monitoring the forum's activities. Such resources could reduce instructors' workload and improve the forum, while streamlining the instructor's evaluation and facilitating student feedback. The effectiveness of this media and forum, as stated by de Lima et al (2019), has supported the study of Akhtar and Azmi (2017), who have stated that top management should ensure that an appropriate information delivery process is established in the organization, and that the effectiveness of the quality management system is communicated to all members of the organization. In this case, top 
management should also guarantee that a suitable venue exists for people of the organization to discuss on concerns pertaining the efficacy of the quality management system. This can be accomplished through meetings, a dialogue suggestion box system, briefings, accomplishment recognition, notice boards, in-house journals, audio-visual media, electronic media, and so on.

\section{Tax Compliance in Malaysia}

Tax non-compliance is a notable problem that are continuously faced by most tax authorities, including the Malaysian Inland Revenue Board (IRBM). In this sense, the Inland Revenue Board of Malaysia (IRBM) is a high-profile organization and the main agency under the Ministry of Finance that collects and administers the direct taxes of the country. Under the Inland Revenue Board of Malaysia Act 1995, the IRBM was established to acquire more control, particularly in the field of hiring and personnel management, to improve the standard of tax administration. In line with this, Saad $(2009,2012)$ has found that people residing in Malaysia feel that the tax system in the country is fair. However, he could not find any facts which would state that this fairness of the tax system had any effects on the tax compliance behavior. He also has identified that the taxpayers of New Zealand felt that the tax system in their country was not just. However, New Zealanders still showed higher levels of compliance than Malaysians. Ortega, Ronconi, and Sanguinetti (2016) have stated that taxpayers would willingly pay taxes, only if they see that the money paid by them is invested well by the government. This is called the principle of reciprocity that can be referred to as a social norm, in which positive action is exchanged for positive action. Basically, if the government utilizes the revenue earned from taxes greatly, the taxpayers are more likely to pay more taxes. On the contrary, if the taxpayers feel that the government is wasting the amount received by them, then they may not view the act of paying taxes as means of reciprocating to the government. Instead, they will be more reluctant at the time of paying taxes. Tax compliance does not only mean complying with the rules and regulations of the tax system of a country, but it has another connotation. Tax compliance has been bifurcated into two perspectives, namely compliance in terms of administration and compliance in terms of correctly filing tax returns (Chow, 2004). From the administrative perspective, it includes giving details about the status of the taxpayer, timely filing of returns, and timely payment of taxes. All this can be done if a person possesses knowledge about the taxation system, along with a degree of honesty in doing all the documentation related work (Palil, 2010).

\section{Factors Affecting Tax Compliance in Malaysia}

Falsetta, Schafer \& Tsakumis (2015) have believed that tax compliance is affected by the alignment of the interest of the taxpayers and the tax-collecting agency. In layman's terms, if the interest of both parties i.e. the taxpayer and the tax collection agency, is similar; then a higher amount of taxable income is earned. This fulfilment of goals for both of the parties is referred to as goal congruence. In addition, taxpayers' compliance decisions are also influenced by audit profitability, especially in cases when the taxpayer supports government usage of the revenue collected. Sometimes a taxpayer may not be in favor of the programs that are run by the government; in such cases, irrespective of high audit profitability, the level of tax compliance will be low. Thus, in order to extract more revenue from people, the government has made sure that such strategies and policies are formulated, which thereby matched the interest of the taxpayer and the collection agency. If the goals are aligned, the taxpayers would themselves show voluntary compliance. The results from the studies have 
revealed that audit profitability is not the only factor to increase compliance, as other factors actually exist. The government's capability to convince a taxpayer about the utilization of the revenue collected by them can also affect compliance behavior. If the government successfully convinces its people that the revenue generated through tax collection benefits them, voluntary compliance can be observed among the people. In this regard, trust is a deciding factor of tax compliance, as it has the ability to enhance the relationship that exists between a taxpayer and tax authority. If the amount of trust between both parties is high, i.e. if a taxpayer exhibits high trust in the tax authority, it is perceived that tax compliance shall be increased; whereas if a taxpayer has low trust in the tax authority, tax compliance is expected to be low (Kastlunger et al., 2013). To relate, Wahl et. al (2010) have found that trust has a positive effect on tax payment. This means that, in a tax system that is perceived to be highly reliable and trustworthy, a high level of tax compliance can be seen. This compliance can either be enforced by the officials or it can be voluntary as well. Similar kinds of results could be observed in the paper of Muehlbacher et al (2011); Kogler et al (2013), in which they saw that trustworthiness of tax authority leads to higher levels of voluntary tax compliance.

\section{The Ability Of Communication Strategies Implementation}

It is possible to understand the correct choice of communication tools; as a contact tool or collaboration, between two or more people that are called as an audience. Supportive management, backed by the use of simple, explicit and precise messaging directed at suitable personnel, would have a reliable, dedicated and highly efficient impact on the pursuit of achieving the aims of IRBM and the Government of Malaysia to draw the attention of taxpayers in Malaysia, in light of tax enforcement. In order to facilitate successful two-way communication within the organisation, the use of relevant and explicit words is required. $A$. Rahim (1993) has argued that the selection of communication tools should follow the hierarchy of communication effectiveness, such as the first level takes into account the language of bilateral communication, whereas the second level should be through two-way communication, but not face to face. The third level, as the less effective communication, is done through a one-way process such as writing a letter or report. The use of relevant media/ forums is capable to convey a message faster, more transparently with minimal monitoring. Management and all levels of employees can access information more easily than ever before and thus, produce new insights and knowledge faster. At the same time, the enormous amount of information received would save organizational members from spending too much time reading, analyzing, organizing and managing information data. Abdullah and Tahir (2014) have suggested that recent technical advances should be able to take advantage of management. This is because there are numerous apps that make contact possible without hindrance, such as WhatsApp, Telegram, WeChat, Facebook and so on. In the meantime, information technology is seen, by Abdul Aziz (2016), as having a positive influence on the company and its top executives. This is because, with the aid of communication technologies, the operations in the company will be changed and it needs the collaboration and attention of both stakeholders to ensure that the selected technology would lead to a positive effect. The study also has showed that organisations that employ communication technologies successfully would accomplish targets quicker and be able to supply other companies with competition. 


\section{Discussion}

This section will address the strategic communications in promoting tax compliance in Malaysia. The basic purpose of this article is to show the extent as to which IRBM benefits from their strategic communication that they have utilized in the organization to advance and achieve their goals. In this context, the research questions posed in the introduction can be answered as follows: Skilled organizations and successful strategic communications continue to feed their publications and media with materials: press releases, campaigns, social media, spectacular events, visual materials and more a symbolic message to the target audience as a taxpayer. The IRBM has achieved it; through intense expertise in the area of marketing relations and promotional operations, IRBM will gain its status in the true meaning of strategic communication. In this matter, IRBM's top management plays significant part in motivating all layers of IRBM workers to be a group of people who collaborate together for accomplishing objectives that cannot be achieved on their own (Ahmad, 2006).

This is due to the fact that a successful organization requires the support of all stakeholders (Awang \& Abdullah, 2012). With a collaboration strategy, the company can collect details quickly and can provide employees and the community with knowledge on the problem. With the nature of strong work culture, combined with good organizational methods; however, it is not difficult for all orders, workers and supervisor partnerships and disputes to be properly executed and resolved (Sulaiman, 2015). By employing strategic contact, organizations could achieve consistent feedback as a consequence of successful engagement between management and employees (Ghani \& Che Ahmad, 2008).

The main thing that needs to be applied is the use of language that would be easy to be understood and encourage staff to give ideas, clear instructions and a conducive atmosphere in the workplace. This is due to the fact that communication strategies are also included in the main thrust of communication, and strategy has become the basis, in which every effective communication depends on strategic planning. Leaders also need to analyze the audience in each situation and develop strategies that would achieve the goal (Barret, 2006). In addition, Barret also has emphasized that good communication depends on strategy, but as the audience becomes more diverse and larger, the communication strategy becomes more complex. Next, in order to ensure effective message delivery, we need to realize that communication involves the delivery of ideas and feelings, in a way that is easy to be comprehended. By targeting the right audience with clear audience characteristics to target, IRBM can deliver a message that is transparent, creative, useful and relevant to the target audience. Since communication is a two-way process, the manager in an organization does not only act as a communicator of information, but in other situations, is also a target for the reception of information (Noh \& Yusof, 2011).

\section{Conclusion}

The paper above discusses the IRBM's use of strategic communication to improve tax compliance among Malaysian taxpayers, namely strategic supporting management, strategic focused message, and strategic effective media/forum. This planned strategic communication is an instrument for IRBM to achieve its objectives in carrying out its obligations as the official tax collecting agent designated by the Malaysian government. This responsibility binds IRBM's commitment to the initial step of organizing internal strategies among all levels of employees, including top management, while mobilizing energy and efforts to formulate various effective communication strategies in order to form a work team to achieve organizational goals in meeting the Government's tax collection targets. The Employee Communication Strategy 
(SEC) used by Barret is a comprehensive model compared to other strategy models, owing to the fact that this model focuses on the best definition and develops management's understanding on the strategic role of employee communication in high-performing companies. In this sense, Barret's model diagnoses the company's strengths and weaknesses relating to employee communication, so that the company can devise change communication and position communication programs to facilitate the overall facility program. The importance of each of the concepts and models mentioned above has its own motive and focus, but is not as comprehensive as the Barret model. Therefore, this article brings a comprehensive discussion in developing the knowledge of the SEC, especially the idea of Barrett that is given less attention. At the same time, after complete analysis, the results that have showed that there is a significant relationship between the communication technique adopted by the public sector and people's willingness to pay taxes. The study is based entirely in Malaysia and has covered all of the aspects related to the taxation system in the country. It also gives an idea about the tax structure of the country and all the measures adopted by the government to stop tax evasion and non-compliance; in which there are plenty of studies available on tax compliance, but they have not been well studied, especially in the context of strategic communication at IRBM Malaysia.

\section{References}

A. Rahim, S. (1993). Komunikasi Asas. Kuala Lumpur : Dewan Bahasa dan Pustaka

Abd. Ghoni, S., Othman, A., \& Abas, N. (2017). Kajian keberkesanan penyampaian maklumat di Jabatan Kejuruteraan Elektrik, Polimas. e-Proceeding National Innovation and Invention Competition Through Exhibition (iCompEx17) (hlm. 1-9).

Abdul Aziz A. (2016). Peranan teknologi komunikasi dan sumbangannya ke arah perkembangan komunikasi dalam organisasi yang berkesan. Forum Komunikasi, 11(2), 51-64.

Abdullah, M. H. A., \& Tahir, M. L. (2014). Amalan perkongsian ilmu di Institusi Pendidikan Teknikal Mara. International Seminar on Technical and Vocational Education 2014 (TVEIS 2014) (hlm. 384- 405).

Abdullah, M. Y. (2002). Merancang kempen komunikasi berasaskan penilaian formatif. Jurnal Komunikasi: Malaysian Journal of Communication, 17, 43-56.

Adam, M. N. H., \& Yusof, N. A. M. (2018). A comparative study on the burden of tax compliance costs amongst GST registered companies in Malaysia and abroad. Journal of Science, Technology and Innovation Policy, 3(2), 33-39.

Ahmad, A. M. (2006). Komunikasi di tempat kerja. Kuala Lumpur: Dewan Bahasa dan Pustaka.

Akhtar, H., \& Azmi, I. A. G. (2017). Komunikasi Kepimpinan Berkesan: Effective Communication for Leaders. Jurnal Syariah, 25(3), 531-562.

Akilandeswari, V., Kumar, A. D., Pavithra, M., Mariyam, A. T., \& Banu, J. N. (2015). Elements of effective communication. International Journal of Multidisciplinary Research and Modern Education (IJMRME), 1(1), 2452-6119.

Awang, M. S., \& Abdullah, Z. (2012). Hubungan Antara Pertimbangan Pemimpin, Pertukaran Komunikasi, Dan Komitmen Organisasi. Jurnal Komunikasi Malaysian Journal of Communication, 28(1): 121-136

Barret, D. J. (2002). Change communication: Using strategic employee communication to facilitate major change. Corporate Communications: An International Journal, 7(4), 219231. 
Barret, D. J. (2006). Leadership communication: A communication approach for senior-level managers. Handbook of Business Strategy. United Kingdom: Emerald Group Publishing.

Bass, B. M., \& Bass, R. (2008). The Bass Handbook of Leadership: Theory, Research and Managerial Applications. Edisi ke-4. New York: Free Press.

Boyatzis, R. E. (2011). Managerial and leadership competencies: A behavioral approach to emotional, social and cognitive intelligence. Vision: The Journal of Business Perspective 15(2): 91-100.

Bush, T. (2008). Leadership and Management Development in Education. London: Sage Publications Ltd.

Che Noh, C. H., \& Yusof, A. A. (2011). Kemahiran komunikasi interpersonal dalam organisasi. Kuala Terengganu: Penerbit Universiti Malaysia Terengganu.

Chow, C. Y. (2004). Gearing up for the self assessment tax regime for individuals. Tax Nasional, 2nd quarter, 20-23.

Cornelissen, J. (2008). Corporate Communication: A Guide to Theory and Practice. London, Sage.

Day, C., Niekerk, M. V., \& Okumus, F. (2017). The important of strategic communication during change management at Palm College of Hospitality and event management. Journal of Hospitality \& Tourism, 5(3), 87-92.

Doz, Y., \& Kosonen, M. (2008). Fast strategy. How strategic agility will help you stay ahead of the game. Harlow (UK), Wharton School Publishing.

Drew, G. M., \& Ehrich, L. C. (2010). A model of organisational leadership development informing succession development: elements and practices. Academic Leadership Online Journal 8(4) 1-18.

Eccles, R. G., \& Nohria, N. (1991). Beyond the Hype: Rediscovering the Essence of Management. Boston: Harvard Business School Press.

Falsetta, D., Schafer, J. K., \& Tsakumis, G. T. (2015). How government spending impacts tax compliance. SSRN Electronic Journal. 1-43.

Ghani, M. Z., \& Che Ahmad, A. (2008). Strategi untuk mengembangkan kemahiran berkomunikasi kanak-kanak berkeperluan khas. Pendidikan Khas, 8(2), 5-13.

Hallahan, K., Holtzhausen, D., Ruler, B. V., Verčič, D., \& Sriramesh, K. (2007). Defining strategic communication. International Journal of Strategic Communication, 1(1), 3- 35.

Hassan, N., Rahmat, M. M., \& Mohamed, M. Z. (2015). Sistem kawalan dalaman, sokongan pengurusan dan keberkesanan audit dalaman sektor awam di Malaysia. Asian Journal of Accounting and Governance, 6, 1- 12.

Hogan, R., \& Warrenfeltz, R. (2003). Educating the modern manager. Academy of Management Learning and Education, 2, 74-84.

Juholin, E., Åberg, L., \& Aula, P. (2015). Strategic employee communication - what does it really mean? Towards responsible dialogue as a missing piece. In editor Andrea C., Ansgar Z., \& Ralph, Communication Ethics in a Connected World: Research in Public Relations and Organisational Communication, (May 2019), 323-345. Peter Lang. https://doi.org/10.3726/978-3-0352-6555-2

Kaplan, R., \& Norton, D. (1992). The Strategy Focused Organisation. How Balanced Scorecard Companies Thrive in the New Business Environment. Boston (KMA), Harvard Business School Press.

Kastlunger, B., Lozza, E., Kirchler, E., \& Schabmann, A. (2013). Powerful authorities and trusting citizens: the slippery slope framework and tax compliance in Italy. Journal of Economic Psychology 34: 36-45. 
King, C. L. (2009). Emergent communication strategies. International Journal of Strategic Communication, 4(1), 19-38.

Klein, S. M. (1996). A management communication strategy for change. Journal of Organizational Change Management, 9 (2), 32-46.

Kogler, C., Batrancea, L., Nichita, A., Pantya, J., Belianin, A. \& Kirchler, E. (2013). Trust and power as determinants of tax compliance: testing the assumptions of the slippery slope framework in Austria, Hungary, Romania and Russia. Journal of Economic Psychology 34, 169-180.

Kouzes, J. M., \& Posner, B. Z. (2002). The Leadership Challenge. Edisi ke-3. San Francisco: Jossey- Bass.

Lee, J. Y., Park, S., \& Baker, R. (2017). The moderating role of top management support on employees' attitudes in response to human resource development efforts. Journal of Management and Organization, 1-19. doi: 10.1017/jmo.2017.37

Mahbob, M. H., Megat Ali, N. A. S., Wan Sulaiman, W. I., \& Mahmud, W. A. (2019). Komunikasi Strategik dan Peranannya Untuk Mewujudkan Komunikasi Berkesan dalam Organisasi. Jurnal Komunikasi: Malaysian Journal of Communication, 35(2), 49-67. https://doi.org/10.17576/jkmjc-2019-3502-04

Mansor, R., \& Hamzah, M. I. (2015). Kepimpinan Berkualiti: Perspektif mengenai Kompetensi yang diperlukan untuk Memimpin dengan Berkesan. Jurnal Pengurusan, 45, 19.

Mazzei, A. (2010). Promoting active communication behaviours through internal Communication. Corporate Communications: An International Journal, 15(3), 221-234.

Mintzberg, H. (1973). The Nature of Managerial Work. New York, Harper \& Row.

Makhbul, M. Z., \& Hasun, M. F. (2003). Mengurus latihan dan kerjaya: Ke arah meningkatkan kesetiaan pekerja. Petaling Jaya: Leeds Publications.

Mohd. Nasurdin, A., Osman, I., \& Ahmad, Z. A. (2006). Pengantar pengurusan (Siri pendidikan jarak jauh). Kuala Lumpur: Utusan Publications \& Distributors Sdn Bhd.

Muehlbacher, S., Kirchler, E. \& Schwarzenberger, H. (2011). Voluntary versus enforced tax compliance: empirical evidence for the "slippery slope" framework. European Journal of Law Economic 32: 89-97.

Murphy, G. (2008). Communication strategy: A best practice guide to developing communication campaigns. United Kingdom, IPA Royal Charter

Omar, F. I., Rosli, H. F., Zakaria, N. A., \& Abdullah, D. N. N. (2015). Hubungan penggunaan media sosial dan penerimaan mesej dakwah. Proceeding of the 2nd International Conference on Management and Muamalah 2015 (2nd ICoMM) (hlm. 181- 191).

Ortega, D., Ronconi, L., \& Sanguinetti, P. (2016). Reciprocity and willingness to pay taxes: evidence from a survey experiment in Latin America. Economía, 16(2), 55-87.

Palil, M. R. (2010). Tax Knowledge and Tax Compliance Determinants in Self-Assessment System in Malaysia. Journal of International Development, 4(3), 61-1. https://doi.org/10.1787/9789264045743-en

Pate, R. R., \& Buchner, D. M. (2013). Implementing physical activity strategies. United States: Human Kinetics.

Saad, N. (2012). Tax non-compliance behaviour: Taxpayers view. Procedia-Social and Behavioral Sciences, 65, 344-351.

Shao, Z., Feng, Y., \& Hu, Q. (2016). Effectiveness of top management support in enterprise systems success: A contingency perspective of fit between leadership style and system lifecycle. European Journal of Information Systems, 25(2), 131-153. doi: 10.1057/ejis.2015.6 
Spendlove, M. (2007). Competencies for effective leadership in higher education. International Journal of Educational Management 21(5): 407- 417.

Steyn, B. (2004) From strategy to corporate communication strategy: a conceptuali- zation. Journal of Communication Management, 8 (2), 68-83.

Wahl, I., Muehlbacher, S., \& Kirchler, E. (2010). The impact of voting on tax payments. Kyklos, 63(1), 144-158.

Walker, R. (2011). Strategic management communication for leaders (2nd ed.). United States of America: Cengage Learning.

Sulaiman, W. I. (2015). Hubungan pengurusan maklumat dengan kepuasan komunikasi dalam kalangan kakitangan kumpulan sokongan sektor awam (PhD thesis, Universiti Putra Malaysia).

Young, R., \& Poon, S. (2013). Top management support: Almost always necessary and sometimes sufficient for success: Findings from a fuzzy set analysis. International Journal of Project Management, 31(7), 943-957. doi: 10.1016/j.ijproman.2012.11.013

Zakaria, N. N. (2012). Kesan kualiti audit dan sokongan pengurusan terhadap keberkesanan fungsi audit dalaman sektor awam di Malaysia (Tesis Sarjana, Program Perakaunan, Graduate School of Business, Universiti Kebangsaan Malaysia, Bangi).

Zerfass, A., \& Huck, S. (2007) Innovation, Communication, and Leadership: New Developments in Strategic Communication. International Journal of Strategic Communication, 1 (2), 107-122.

Zookefli, Z., \& Nor, M. K. (2008). Hubungan budaya organisasi dengan perkongsian pengetahuan. Jurnal Kemanusiaan, 11, 68- 79. 